\title{
Pelatihan Manajemen Keuangan untuk Wirausaha Kecil Pada UMKM Kalipakem, Pundong, Bantul, Daerah Istimewa Yogyakarta
}

\author{
Bhenu Artha \\ email: bhenoz27@gmail.com \\ Prodi Kewirausahaan, Fakultas Ekonomi \\ Universitas Widya Mataram
}

\begin{abstract}
The purpose of this activity is to improve the performance of business by increasing the potential of SMEs in Kalipakem so that it has implications on poverty alleviation efforts. This activity uses public education methods accompanied by training, by means of counseling to improve the understanding and awareness of the participants, also conducted demonstrations for the preparation of simple financial statements followed exercises for each participant to make cash planning and managing finances. The trainees are the mothers of SMEs in Kalipakem, Pundong, Bantul, as many as 18 participants. Before following the practice, the recording is not routine so that transactions are not included in the financial statements of SMEs. After following community service activities participants were able to compose a simple financial report.
\end{abstract}

Keywords: SMEs, simple financial report

\begin{abstract}
Abstrak
Tujuan kegiatan pengabdian ini adalah meningkatkan kinerja usaha dengan peningkatan potensi masyarakat UMKM Kalipakem sehingga memiliki implikasi pada upaya penanggulangan kemiskinan. Kegiatan ini menggunakan metode pendidikan masyarakat disertai pelatihan, dengan cara penyuluhan untuk meningkatkan pemahaman serta kesadaran para peserta, juga dilakukan demonstrasi untuk penyusunan laporan keuangan sederhana diikuti latihan bagi masing-masing peserta untuk membuat perencanaan kas dan mengelola keuangan. Peserta pelatihan yaitu ibu-ibu pelaku UMKM di Kalipakem, Pundong, Bantul sebanyak 18 peserta. Sebelum mengikuti latihan pencatatan dilakukan tidak rutin sehingga tedapat transaksi yang tidak masuk dalam laporan keuangan UMKM. Setelah mengikuti kegiatan pengabdian masyarakat peserta mampu untuk menyusun laporan keuangan sederhana.
\end{abstract}

Kata kunci: UMKM, laporan keuangan sederhana

\section{PENDAHULUAN}

Perkembangan ekonomi diartikan sebagai suatu proses kegiatan yang dilakukan oleh suatu bangsa dalam upaya untuk meningkatkan pendapatan dan kesejahteraan yang dilakukan terus menerus dalam jangka waktu yang panjang (Muhammad dan Rozali, 2017). Tujuan mulia dari globalisasi ekonomi adalah menciptakan kesejahteraan umat manusia di dunia dengan saling mencukupi kebutuhan antar bangsa melalui transaksi ekonomi (Mukti Fajar, 2016: 74).

Usaha Mikro Kecil Menengah (UMKM) di Kalipakem, Pundong, Bantul merupakan binaan Koperasi AKU Sejahtera. Pembinaan ini bertujuan memecahkan satu masalah UMKM yaitu permodalan. Modal usaha yang berasal dari Koperasi AKU Sejahtera digunakan untuk 
pengembangan usaha UMKM di Kalipakem, Pundong, Bantul.

Permasalahan yang masih ditemukan pada UMKM di Kalipakem, Pundong, Bantul salah satunya adalah para pelaku belum mampu memberikan laporan keuangan secara sistematis tentang perkembangan usahanya. UMKM Kalipakem masih menggunakan pengelolaan dengan manajemen kekeluargaan, yaitu dalam menjalankan kegiatan usahanya belum memisahkan antara kekayaan pribadi dan kekayaan UMKM sehingga tidak dapat diketahui secara jelas berapa jumlah kekayaan pribadi dan kekayaan UMKM, bagaimana perkembangan modal usaha dan berapa perolehan pendapatan dan juga keuntungan jumlahnya tidak dapat diketahui secara pasti. Selain itu kondisi usaha yang tidak stabil dan banyaknya keperluan pribadi yang masih bercampur dengan kekayaan UMKM juga memungkinkan bahwa kekayaan pribadi digunakan untuk memenuhi kebutuhan UMKM.

Selain pada manajemen usaha yang belum ada pemisahan secara jelas antara kekayaan pribadi dan kekayaan UMKM, permasalahan lain yang dihadapi UMKM Kalipakem adalah masalah pencatatan administrasi. Selama ini pencatatan transaksi tidak dilakukan secara rutin oleh pemilik. Pencatatan hanya sebagian kecil saja ketika pemilik merasa perlu dan transaksi yang diingat oleh pemilik saja. Hal ini memungkinkan ada transaksi yang tidak tercatat yang akan berdampak pada akuntabilitas dari laporan yang dibuat berdasarkan catatan transaksi. Karena pencatatan hanya sebagian kecil saja membuat pemiliki juga menemukan kesulitan dalam mengidentifikasi dan memulai pencatatan. UMKM Kalipakem juga memiliki keterbatasan dalam mengakses informasi dan keengganan dalam merekrut tenaga administrasi/ tenaga ahli untuk berdiskusi, karena pertimbangan biaya.
Tujuan kegiatan pengabdian ini adalah meningkatkan kinerja usaha dengan peningkatan potensi masyarakat UMKM Kalipakem sehingga memiliki implikasi pada upaya penanggulangan kemiskinan.

\section{METODE PENELITIAN}

Pelaksanaan pengabdian dilakukan di Kalipakem, Pundong, Bantul menggunakan metode pendidikan masyarakat disertai pelatihan, dengan cara penyuluhan untuk meningkatkan pemahaman serta kesadaran para peserta, juga dilakukan demonstrasi untuk penyusunan laporan keuangan sederhana diikuti latihan bagi masingmasing peserta untuk membuat perencanaan kas dan mengelola keuangan. Mitra pelatihan yaitu ibu-ibu pelaku UMKM di Kalipakem, Pundong, Bantul sebanyak 18 peserta. Pendidikan dan pelatihan keuangan ini dilakukan dengan cara penyuluhan, disertai demonstrasi dan latihan menyusun laporan keuangan sederhana dengan melakukan praktik langsung/learning by doing (Rosita, Kusasih \& Istiyanto, 2017). serta diskusi terhadap masalah keuangan keluarga yang dihadapi para peserta. Materi yang disampaikan yaitu manajemen keuangan sederhana.

Konsep pengabdian masyarakat melalui peningkatan kapasitas atau kemampuan perencanaan kas keuangan keluarga maupun manajemen keuangan keluarga ini mengacu kepada prinsip pemberdayaan masyarakat menurut Soetomo (2012), dimana fokus ditujukan pada komunitas sebagai sesuatu yang utuh/bulat, berorientasi pada kebutuhan dan permasalahan, dengan mengutamakan prakarsa, partisipasi, dan swadaya masyarakat. Dari segi proses, Mardikanto \& Subianto, (2012) menyatakan proses pemberdayaan masyarakat merupakan upaya yang sengaja dilakukan untuk memfalisitasi masyarakat lokal dalam merencanakan, memutuskan, dan mengelola sumber daya lokal yang dimiliki melalui collective action dan 
networking sehingga mereka memiliki kemampuan dan kemandirian secara ekonomi, ekologi, dan sosial. Usman (2004) mengemukakan beberapa strategi yang dapat menjadi pertimbangan untuk dipilih dan diterapkan dalam pemberdayaan masyarakat, yaitu menciptakan iklim, memperkuat daya, dan melindungi.

\section{HASIL DAN PEMBAHASAN}

Gambaran umum mengenai aspek keuangan UMKM adalah permodalan sebagian besar bersumber dari Bank/Koperasi (100\%), dana operasional cukup tersedia $(83,33 \%)$, mayoritas pelaku UMKM memiliki rekening di bank (100\%), pengelolaan keuangan ditangani pemilik $(94,44 \%)$, kesulitan mengakses kredit perbankan atau koperasi $(11,11 \%)$, modal kerja usaha berbentuk kas $(94,44 \%)$ dengan kondisi lancar (100\%) sedangkan aktiva lancar berupa persediaan barang dagangan jumlahnya cukup $(83,33 \%)$. Kinerja usaha dilihat dari keuntungan selama dua tahun terakhir menunjukkan kecenderungan stabil $(94,44 \%)$. Derajat pengelolaan keuangan usaha kecil diperoleh dari jawaban 10 butir pertanyaan yang diberikan oleh responden yang diberi nilai 0 untuk jawaban "Tidak Ada", serta skor 1,2 dan 3 untuk jawaban "Ada" dalam kondisi "kurang", "cukup" dan "baik". Berdasarkan analisis diperoleh 50\% responden tidak menyimpan bukti transaksi, 55,56\% responden melakukan pencatatan transaksi keuangan, aliran kas dan perencanaan kas, $66,67 \%$ responden tidak mempunyai perencanaan keuntungan usaha, 11,11\% responden melakukan pengawasan atas terjadinya penyimpanan terhadap anggaran kas, $50 \%$ responden melakukan pengendalian terhadap keuntungan, 55,56\% responden melakukan pemisahan antara kekayaan pribadi dan usaha. Perencanaan dan pengendalian keuangan serta pembukuan praktis untuk usaha kecil, juga wawasan tentang pemisahan kekayaan pribadi dan usaha menjadi kebutuhan pengetahuan yang harus dimiliki oleh pelaku UMKM.

Sebelum mengikuti latihan pencatatan dilakukan tidak rutin sehingga tedapat transaksi yang tidak masuk dalam laporan keuangan UMKM. Setelah mengikuti kegiatan pengabdian masyarakat peserta mampu untuk menyusun laporan keuangan sederhana.

\section{PENUTUP}

Kegiatan pelatihan dapat meningkatkan kemampuan mitra dalam melakukan pengelolaan terhadap usahanya, terutama dalam bidang manajemen keuangan, yang dapat meningkatkan kemampuan pelaku UMKM dalam penyusunan laporan keuangan sederhana.

Saran untuk pengabdian masyarakat selanjutnya adalah memberikan pelatihan dalam hal kewirausahaan, manajemen organisasi, manajemen pemasaran, terutama pemasaran produk UMKM.

\section{UCAPAN TERIMA KASIH}

Ucapan terima kasih disampaikan kepada ibu-ibu pelaku UMKM di Kalipakem, Pundong, Bantul yang berpartisipasi dalam kegiatan pengabdian masyarakat ini.

\section{DAFTAR PUSTAKA}

Dantes, Nyoman. 2012. Metode Penelitian. Yogyakarta. Andi Offset.

Fajar, Mukti ND. 2016. UMKM di Indonesia Perspektif Hukum Ekonomi. Yogyakarta. Pustaka Pelajar

Gitman, Lawrence J. dan Zutter, Chad J. 2014. Principles of Managerial Finance. Essex, England. Pearson 
Haliman dan Yuniarwati. 2014. Pertumbuhan Ekonomi, Seharusnya Terdapat Keterpaduan Antara Pemerintah, Dunia Usaha dan Masyarakat Untuk Mencapai dan Mempertahankan Kesempatan. Seminar Nasional Kewirausahaan dan Inovasi Bisnis. Vol V.

Ikatan Akuntan Indonesia. 2007. Standar Akuntansi Keuangan. Jakarta: Salemba Empat

Kasiram. 2010. Metodologi Penelitian Kualitatif dan Kuantitatif. Yogyakarta. UIN-Maliki Press

Mardikanto, T. dan Subianto, P. 2012. Pemberdayaan Masyarakat dalam Perspektif Kebijakan Publik. Bandung. Alfabeta.

Meslier, Celine, Sauviat, Alain dan Yuan, Dian. 2020. Comparative advantages of regional versus conventional banks in alleviating SME's financial constraints. International Review of Financial Analysis.

https://doi.org.10.1016/j.irfa.2020. 101471
Muhammad, Farhana dan Rozali, Toyib. 2017. Pengaruh Kredit Usaha Rakyat Terhadap Pendapatan Usaha Mikro Dan Kecil Di Desa Selagik Kecamatan Terara Kabupaten Lombok Timur Provinsi Nusa Tenggara Barat (Studi Kasus Bank BRI Unit Terara). JPEK 1(1): 38-48

Rosita, Kusasih, I.A.K.R., dan Istiyanto, B. 2017. Perbaikan Pengelolaan UMKM Guna Pengembangan Usaha Mikro. Jurnal Pengabdian dan Pemberdayaan Masyarakat. 1(1), 3037.

Soetomo. 2012. Pembangunan Masyarakat. Yogyakarta. Pustaka Pelajar.

Undang-Undang Republik Indonesia Nomor 10 Tahun 1998 Tentang Usaha Mikro, Kecil, dan Menengah.

Usman, S. 2004. Pembangunan dan Pemberdayaan Masyarakat. Yogyakarta. Pustaka Pelajar. 